\title{
АНАЛІЗ СОЦІАЛЬНИХ ІНДИКАТОРІВ ЕПІДЕМІї ТБ / ВІЛ В УКРАЇНІ
}

\author{
() І. О. Федяк, П. І. Федяк
}

\author{
ДВНЗ «Івано-Франківський національний медичний університет» \\ Irynaf@tvnet.if.ua
}

\begin{abstract}
Мета роботи. Базуючись на аналізі даних медичної карти стаціонарного хворого Ф003/о, визначити і оцінити соціальні індикатори ко-інфекції ТБ/ВІЛ в Україні.

Матеріали і методи. 1200 медичних карт стаціонарних хворих на ТБ / ВІЛ у діапазоні нозологій «А15-А19 Туберкульоз» з ВІЛ-інфекцією, випадково відібрані з архівів 12 обласних протитуберкульозних диспансерів (зі збереженням таємниці персональних даних хворих); соціологічний метод аналізу документів (формалізований, контент-аналіз).

Результати й обговорення. Досліджувану вибірку пацієнтів із ТБ / ВІЛ на 91\% склали непрацюючі особи, які потребують постійного соціального супроводу. 3 усіх виписаних лише 49,34\% хворих закінчили стаціонарний етап лікування, який у середньому тривав $116 \pm 93$ ліжко-днів; 25,25\% осіб були виписані за порушення лікарняного режиму (18\% - самовільно залишили стаціонар, 7,25\% - порушили інші правила перебування). Оскільки найвища частка працюючих осіб із ТБ / ВІЛ виявилася в областях найвищої поширеності ВІЛ-інфекції: Одеській (17,14\%), м. Києві (14,81\%), Дніпропетровській (13,6\%), Запорізькій (13,33 \%), можна припустити, що ВІЛ-інсрекція в Україні виходить за межі «груп ризику».

Висновки. У межах областей аналізу за соціально-демографічними характеристиками хворі на ТБ / ВІЛ були у 72,25 $\pm 8,33 \%$ випадків чоловіками (ймовірність належати до жіночої статі зростала в областях найвищої

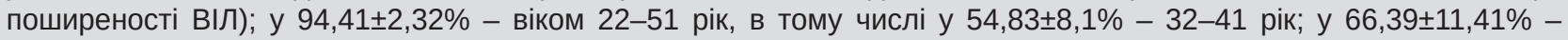
проживали у містах; у 90,84 $5,09 \%$ - належали до соціально незахищених верст суспільства: були безробітними працездатного віку $(69,17 \pm 8,97 \%)$, інвалідами $(19,92 \pm 10,71 \%)$, пенсіонерами $(0,83 \pm 1,31 \%)$, перебували у декретній відпустці $(0,67 \pm 0,99 \%)$, студентами $(0,25 \pm 0,56 \%)$, у тому числі належали до осіб без постійного місця проживання $(2,33 \pm 2,56 \%)$, були внутрішніми переселенцями $(0,92 \pm 1,7 \%)$, засудженими $(0,75 \pm 0,69 \%)$. Водночас соціальні індикатори ТБ/ВІЛ, які стосуються перебування хворих у протитуберкульозних закладах, найперше залежали від регіону проживання.
\end{abstract}

Ключові слова: ко-інфекція ТБ / ВІЛ; медична карта стаціонарного хворого Ф003/о; соціальні-індикатори; соціально-демограсрічні характеристики індивіда; причина виписки хворого, ліжко-день.

Вступ. Епідемія вірусу імунодеоріциту людини (ВІЛ) справила величезний вплив на епідемію туберкульозу (ТБ). 3 поширенням ВІЛ захворюваність на ТБ різко підвищилася як в ендемічних країнах, так і в тих, де раніше частота ТБ знижувалася. Зменшуючи можливість імунної системи відповідати на мікобактерійну інфекцію, ВІЛ збільшує чутливість до туберкульозної інфекції. Загальні соціальні фрактори ризику разом з прискореним перебігом захворювання, призводять до того, що іноріковані ВІЛ пацієнти мають значно вищий ризик смерті від ТБ [1-6]. Так, у своєму Звіті за 2016 р., присвяченому глобальній епідемії ТБ та заходам ії̈ протидії, Всесвітня організація охорони здоров'я (ВООЗ) заявила, що ТБ залишається однією з найпоширеніших причин смерті людей, що живуть з ВІЛ [1].

За даними Міністерства охорони здоров'я України (МОЗУ), в Україні щороку зростає кількість хворих одночасно на ТБ та ВІЛ: у 2015 р. цей показник склав 13,0 осіб на 100 тис. населення за статистичними да- ними і 20,0 на 100 тис. населення - за розрахунками міжнародних і громадських організацій, що свідчить про низький рівень діагностики ТБ у ВІЛ-хворих [7].

За даними ВООЗ та МОЗУ, у питанні подолання ТБ у світі та в Україні залишаються високий тягар мультирезистентного туберкульозу (МРТБ) та поєднаність ТБ / ВІЛ-інфекцій, що потребує значних зусиль та ресурсів для їх вирішення [1-3, 6]. Щороку спеціалісти колишнього ДУ «Український центр контролю за соціально небезпечними хворобами МОЗ» (УЦКС), а тепер дУ «Центр громадського здоров'я МОзУ» (ЦГЗ) та ДЗ «Центр медичної статистики МОЗУ» розробляють Аналітично-статистичний довідник «Туберкульоз в Україні» (відповідальні редактори за 2015 р. Н. М. Нізова, М. В. Голубчиков) [8]. Оскільки такий епідеміологічний нагляд за ТБ на усіх рівнях (збір даних, аналіз, розповсюдження) входить до компетенції ЦГЗ $[6,7]$.

Так, за даними експертів УЦКС у 2015 р., 75 \% тих, у кого вперше діагностовано туберкульоз (ВДТБ), -

ISSN 2312-0967. Фармацевтичний часопис. 2017. № 4 
представники незахищених верств населення 58,4 \% 3 них - безробітні особи працездатного віку, $5 \%$ - особи без постійного місця проживання (БПМП), 1 \% - особи, які повернулись з місць позбавлення волі. Серед уперше зареєстрованих хворих на ТБ 12,1 \% становили хворі, які зловживають алкоголем, та $7 \%$ - споживачі ін'єкційних наркотиків [8]. Аналогічною була соціальна структура осіб з новими випадками ТБ у 2016 р., окрім осіб БПМП, частка яких зменшилась до 1,9 \%, що і вплинуло на зменшення частки представників незахищених верств населення до 72,7 \% [7].

Однак дані вітчизняної офріційної статистики по ТБ стосуються ВДТБ, а оцінка соціальних індикаторів ТБ / ВІЛ в Україні потребує вивчення. Окрім того, аналіз результатів реальної клінічної практики займає вагоме місце у методології Оцінки медичних технологій, яка $€$ комплексним підходом, спрямованим на покращення політики прийняття рішень в охороні здоров'я та фрармації $[9,10]$. Нами проводиться інтегрований клініко-економічний аналіз протитуберкульозної терапії, спожитої хворими на ТБ / ВІЛ, який розпочато із вивчення соціально-демографрічних характеристик індивіда, оскільки вони впливають на терапевтичну поведінку осіб в умовах хронічного захворювання, а остання, у свою чергу, на готовність пацієнта виконувати рекомендації лікаря, його сумлінність і схильність до лікування (комплаєнс), що має вирішальне значення при лікуванні як ТБ, так і ТБ / ВІЛ [11].

Мета роботи: базуючись на аналізі медичних карт стаціонарних хворих Ф 003/о, визначити та оцінити соціальні індикатори ко-інфекції ТБ/ВІЛ в Україні, а саме: стать, вік, місцевість проживання, соціальний статус хворих; випадки ТБ за попередньою історією лікування у клінічних діагнозах; код Міжнародної класиорікації хвороб (MKX) на медичних картах; причину виписки; середню кількість ліжко-днів, проведених хворими у протитуберкульозних закладах охорони здоров'я (ПТЗОЗ).

Матеріали і методи. Вибіркова сукупність: 1200 медичних карт стаціонарних хворих на ТБ / ВІЛ фрорми № 003/о були репрезентативні за основними соціально-демографрічними характеристиками індивіда (стать, вік, область проживання, соціальні стани), випадками ТБ на основі попередньої історії лікування, кодом МКХ. Медичні карти були отримані методом випадкового відбору з архівів 12-ти ПТзО3 Вінницької, Дніпропетровської, Запорізької, ІваноФранківської, Київської, Львівської, Миколаївської, Одеської, Рівненської, Тернопільської, Харківської, Херсонської областей (зі збереженням таємниці персональних даних осіб). Окрім ко-інфекції ТБ / ВІЛ, перевага до включення у вибірку надавалась наявній резистентності до протитуберкульозних препаратів (ПТП). Так, кожен із 12 ПТЗОЗ представив у

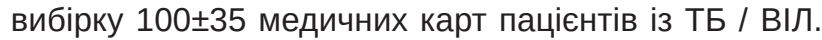

Медичні карти були відібрані за кодами МКХ у діапазоні нозологій «А 15-А 19 Туберкульоз» з ВІЛінсрекцією 4 клінічної стадії. Аналіз проводився у тубдиспансерах тих самих областей, у яких попередньо здійснювався аналіз амбулаторних карт диспансерного нагляду за ВІЛ-інфрікованою особою фрорми №030-5/о $[12,13]$ як фррагмент комплексного дослідження згідно 3 договором від 18.05.2016 р. між УЦКС та ІФНМУ. Окрім того, на роботу з архівними матеріалами було отримано лист підтримки від УЦКС від 17.08.2016 р. № 1713, а у кожному ПТЗО3 - дозвіл головного лікаря.

Для визначення соціо-індикаторів був використаний соціологічний метод аналізу документів [14]. У даному випадку роль документа відігравала медична карта стаціонарного хворого фрорми № 003/о (наказ MO3 №110 від 14.02.2012) [15]. Цей вид документа мав ознаки письмового, ретроспективного (архівного), первинного, офріційного, незалежного від дослідника носія інформації $[16,17]$. Окрім внутрішнього аналізу та аналізу вивчення документа, були використані формалізований (кількісний), який полягав у визначенні кількісних показників за допомогою одиниць обчислювання (абсолютних і відносних - відсоткових значень та їх стандартних відхилень за областями 3 допомогою програми Microsoft Excel 2010) i контент-аналізу (якісно-кількісний метод, який дозволив квантифікувати медичні картки за категоріями 3 подальшою інтерпретацією даних), а також метод графрічного представлення результатів аналізу [14, 16, 17].

Результати й обговорення. 1200 медичних карт стаціонарних хворих на ТБ / ВІЛ були за 2010-2016 роки з найбільшою часткою за 2014-2016 (77,17 \%). На рисунку 1 поданий розподіл карт за статтю та місцем проживання хворих.

Отже, поділ медичних карт за статтю хворих виявив значне домінування частки чоловіків $(72,25 \pm 8,33 \%)$ над жінками $(27,75 \pm 8,33 \%)$, яке характерне для цієї категорії пацієнтів (рис. 1, а). Якщо розглянути гендерні відмінності хворих за областями (рис. 2), то найменший розрив між статями і, відповідно, найвища частка жінок з ТБ / ВІЛ спостерігалися у 3-х областях-лідерах за поширеністю ВІЛ: Миколаївській (39,86 \%), Дніпропетровській $(39,20 \%)$, Одеській $(35,24 \%)$, а найменша - у м. Києві $(17,59 \%)$ та в Івано-Франківській області $(17,81 \%)$.

Результат вивчення місця проживання хворих (рис. 1,6$)$ показав прив'язку до місцевості у пацієнтів із ТБ / ВІЛ, оскільки спостерігалась більш виражена ймовірність ко-інфекції ТБ / ВІЛ для жителів міст, порівняно із сільськими мешканцями $(66,39 \pm 11,41 \%$ та 33,61 11,41 \% відповідно). Аналіз цього показника за областями виявив домінування міських жителів над сільськими у Західному регіоні і 2-х областях Східного регіону (рис. 2).

ISSN 2312-0967. Pharmaceutical review. 2017. № 4 


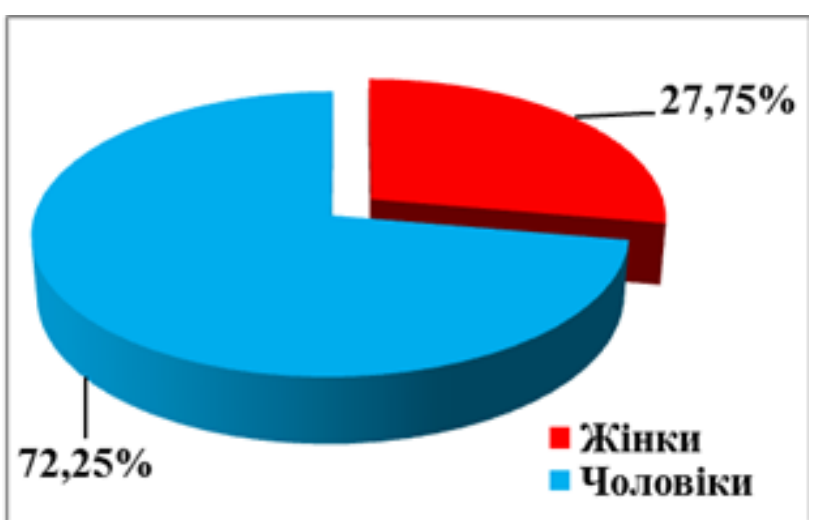

a

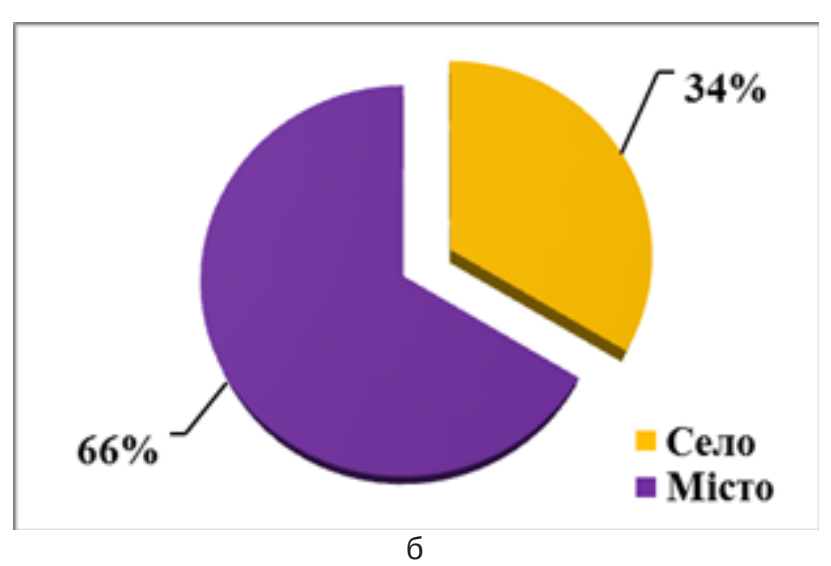

Рис. 1. Розподіл медичних карт первинної вибірки за гендерною ознакою та місцевістю проживання стаціонарних хворих на ко-інфекцію-ТБ / ВІЛ.

Результат аналізу (рис. 2) вказує, що найбільше міських жителів із ТБ / ВІЛ було на Заході, а саме: Львівській, Івано-Франківській, Рівненській, Тернопільській областях (86\%, 78,08\%, 72,5\%, 71,93\% відповідно), а зі східних - у Харківській (80\%) і Запорізькій $(76,19 \%)$. Для решти областей було характерне переважання частки міських жителів на рівні, нижчому за середній, а найвища частка сільського населення була у південних областях: Миколаївській (46,62 \%), Одеській (43,81 \%), Херсонській (42,98 \%).

У подальшому був зроблений розподіл медичних карток за віком та соціальним статусом стаціонарних хворих із ко-інфекцією ТБ / ВІЛ, результат якого представлений на рисунках 2, 3 та 4.

Як свідчать результати дослідження (рис. 2 і 4, а),

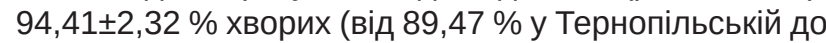
$97,94 \%$ в Івано-Франківській областях) із коінфекцією ТБ / ВІЛ були віком 22-52 роки, з яких $54,83 \pm 8,1 \%$ становили особи від 32 до 41 року. Саме цей віковий проміжок показав найбільшу уразливість до ко-інфекції ТБ / ВІЛ у вибірці загалом та у кожній області зокрема (рис. 2). На 2-му місці за кількістю хворих була вікова група 42-51 рік, частка якої стано-

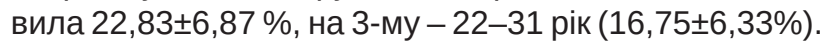
Якщо представити трійку груп-лідерів за віком у вигляді числового співвідношення, то отримаємо: 2231 рік : 32-41 рр. : 42-51 рік як 1 : 3,3 : 1,4, яке наближено зберігалося у більшості областей (рис. 2). Загалом хворих на ТБ / ВІЛ віком 52-61 рік було

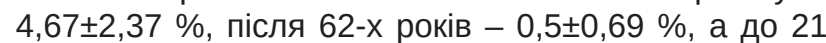
року $-0,42 \pm 0,7 \%$ (рис. 4, a).

Дані аналізу дозволяють стверджувати, що віковий розподіл хворих на ТБ / ВІЛ був наближений до співвідношення за віком амбулаторних хворих на ВІЛ-інфекцію у тих самих областях, яке було досліджено раніше [12, 13].

Соціальну структуру пацієнтів показано на рисунку 3 та 4, б. Виявлено, що загальний відсоток непрацюючого населення у первинній вибірці хворих на ТБ

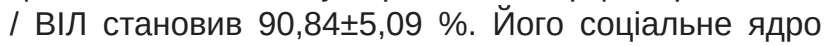

склали власне безробітні особи, яких було

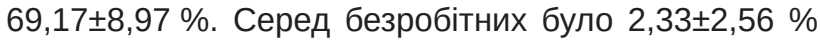
осіб без постійного місці проживання (БПМП),

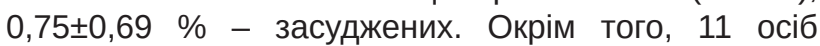
$(0,92 \pm 1,7 \%)$ були внутрішніми переселенцями; 1 особа (0,08 \%) підпадала під дію Закону України «Про статус і соціальний захист громадян, які постраждали внаслідок Чорнобильської катастрофи»; ко-інфекцію ТБ / ВІЛ мали 4 медичні сестри та 1 лікар, що становило 0,33 \% та 0,08 \% відповідно.

Аналіз соціального статусу осіб у ракурсі регіонів виявив, що найменша частка непрацюючих серед стаціонарних хворих на ТБ / ВІЛ і, відповідно, найбільша - працюючих була в областях найвищого розповсюдження ВІЛ-іноекції (окрім Миколаївської): в Одеській (82,86 \% - непрацюючі та 17,14 \% - працюючі), м. Києві (85,19\% та 14,81\% відповідно), Дніпропетровській (86,4 \% та 13,6 \%), Запорізькій (86,67 \% та 13,33 \%). За цими даними напрошується висновок, що в областях найвищого розповсюдження ВІЛ ця інфекція виходить за межі «груп ризику», що $є$ несприятливим фрактом та вказує на зростання ймовірності зараження ВІЛ ширшого кола осіб (рис. 3).

У подальшому було проаналізовано наступний блок соціо-індикаторів, який стосувався перебування пацієнтів у протитуберкульозних диспансерах. Найперше для первинної вибірки медичних карт стаціонарних хворих був визначений спектр клінічних діагнозів у частині випадків, на підставі попередньої історії лікування ТБ (рис. 5, а) та відповідних їм кодів за Міжнародною статистичною класифрікацією хвороб та проблем, пов'язаних зі здоров'ям 10 перегляду (рис. 5, б). Аналізу були піддані як діагнози при госпіталізації, оформлені безпосередньо при звертанні хворого за медичною допомогою; уточнені клінічні, які впливали на терапевтичну тактику; а також заключні - ті, які були вказані у Виписці з медичної картки стаціонарного хворого ТБ 09 чи Протоколі (карті) патологоанатомічного дослідження Ф № 013/o (у випадку смерті пацієнта).

ISSN 2312-0967. Фармацевтичний часопис. 2017. № 4 
Фармакоекономіка

Pharmacoeconomics
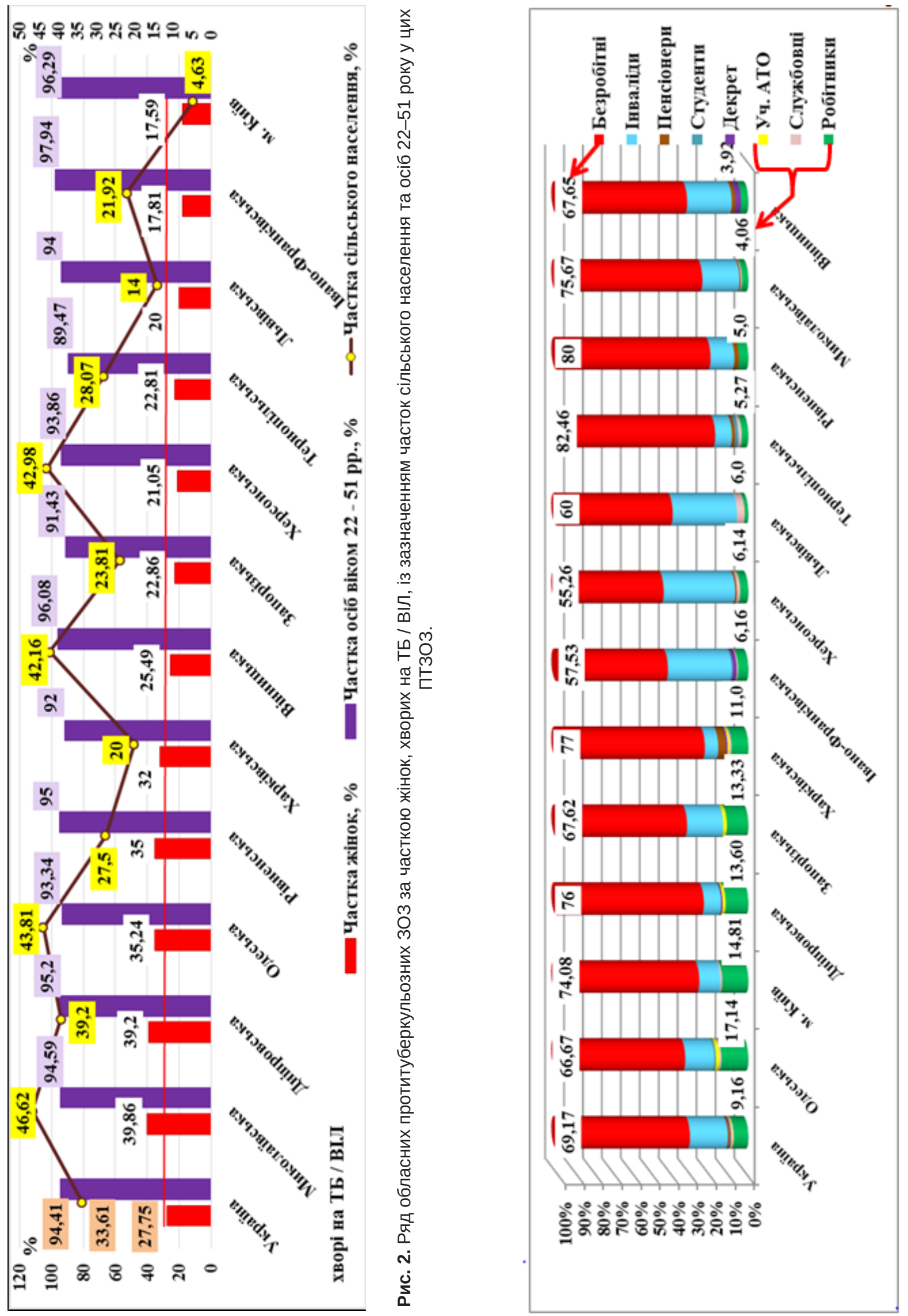

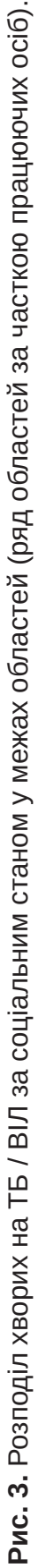

ISSN 2312-0967. Pharmaceutical review. 2017. № 4 


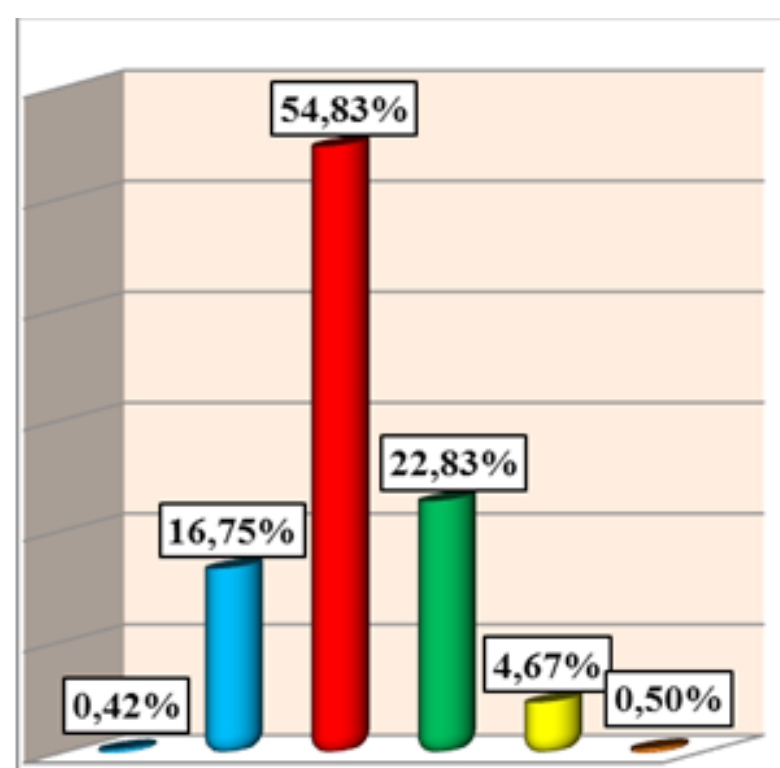

18-21 22-31 32-41 42-51 52-61 62-71 роки

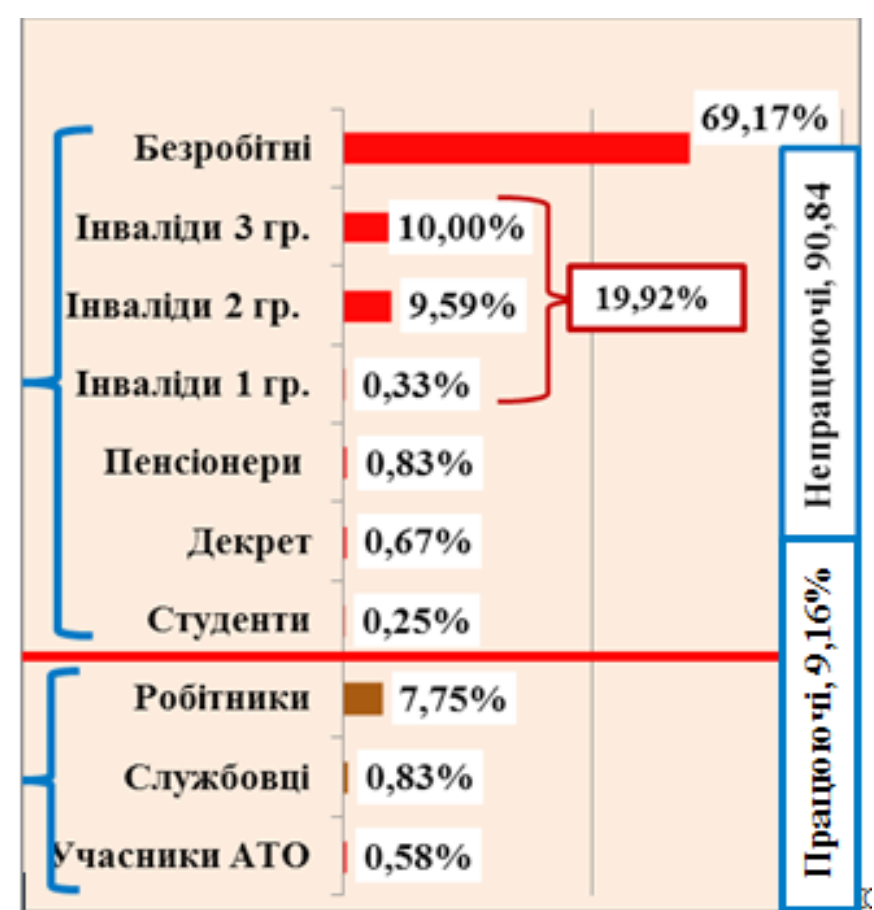

б

Рис. 4. Розподіл медичних карт за віком (а) та соціальним статусом (б) хворих на ко-інфекцію-ТБ / ВІЛ.

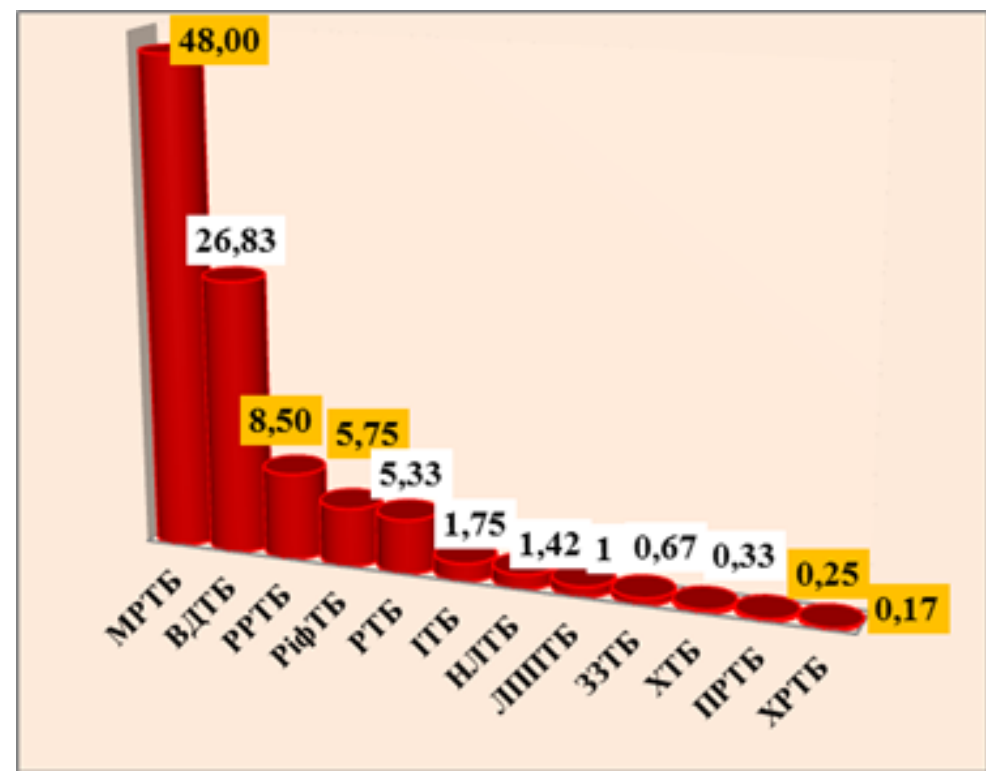

a

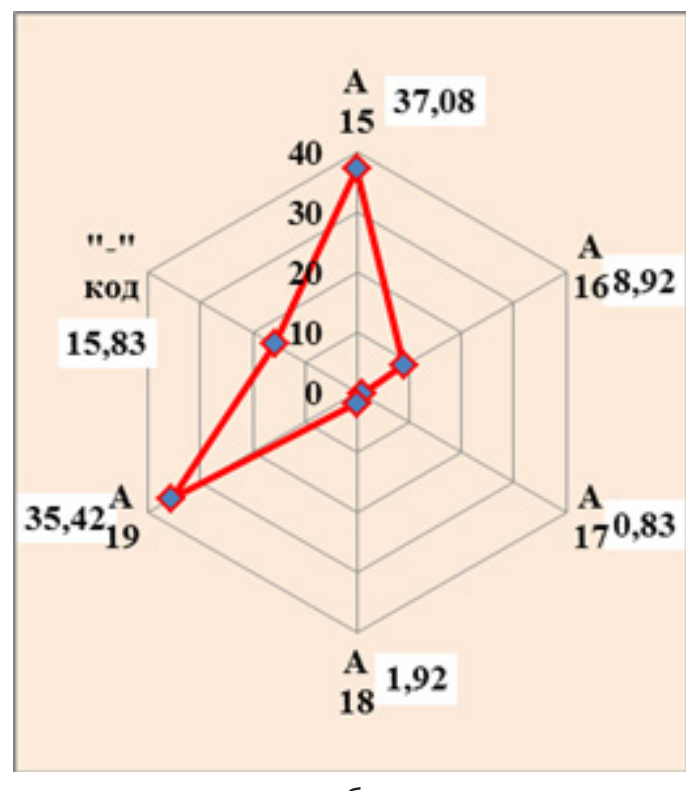

б

Примітки: а) МРТБ - мультирезистентний ТБ, ВДТБ - вперше діагностований ТБ, РРТБ - ТБ із розширеною резистентністю, РіфТБ - ТБ резистентний до рифрампіцину, РТБ - рецидив ТБ, ІТБ - інший ТБ, НЛТБ - невдача лікування випадку ТБ, ЛППТБ - лікування після перерви ТБ, ЗЗТБ - залишкові зміни після вилікування ТБ, ХТБ - хронічний ТБ, ПРТБ - полірезистентний ТБ, ХРТБ - хіміорезистентний ТБ;

б) А 15 - ТБ органів дихання, підтверджений бактеріологічно та гістологічно; А 16 - ТБ органів дихання не підтверджений бактеріологічно та гістологічно; А 17 - ТБ нервової системи; А 18 - ТБ інших органів; А 19 - міліарний ТБ; «-» код відсумній код МКХ.

Рис. 5. Розподіл часток (\%) медичних карт стаціонарних хворих на ко-інфекцію ТБ / ВІЛ за випадками ТБ на підставі попередньої історії лікування (а) та за кодами нозологій блоку «А 15-А 19 Туберкульоз» (б).

ISSN 2312-0967. Фармацевтичний часопис. 2017. № 4 
Отже, серед 1200 медичних карт хворих на ТБ ВІЛ були наявні 12 різновидів нових і повторних випадків ТБ (рис. 5, а). Оскільки під час фрормування первинної вибірки медичних карт перевага на включення надавалася картам хворих із резистентністю до ПТП, то лідером був МРТБ 3 часткою

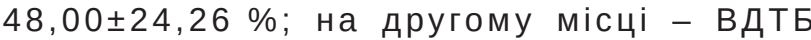

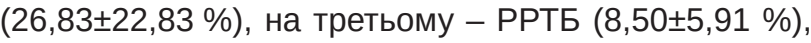

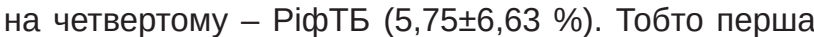
четвірка випадків ТБ у цій вибірці охопила 89,08 \% карт. У подальшому саме вони сформують 2 нові вибірки медичних карток: 3 резистентністю до ПтП (МРТБ, РРТБ, РіфТБ) та зі збереженою чутливістю до ПТП (ВДТБ) для участі у фармакоекономічних дослідженнях. Серед спектру випадків - 5 стосувалися ТБ із резистентністю до ліків, які сукупно у всій вибірці становили 62,67 \% історій хвороб. Це були медичні картки хворих на МРТБ, РРТБ, РіфрТБ і хворі 3 підтвердженими випадками хіміорезистентного ТБ (ПРТБ, ХРТБ), які потребували лікування тривалістю понад 12 місяців.

Аналіз практики виставлення випадків ТБ за попередньою історією лікування у заключних клініч них діагнозах медичних карт хворих вказує на наявність певних регіональних тенденцій. Однак ще більш виражені регіональні підходи були виявлені у кодуванні лікарями медичних карт за МКX-10. При аналізі були виявлені ПТЗО3, які представили широкий спектр шифрів діагнозів: 14-20 (Дніпропетровська, Херсонська, Одеська, Івано-Франківська). Одночасно у Миколаївській, Рівненській областях та м. Києві була відзначена практика присвоєння 1-4 типових шифрів. Загалом аналіз кодів МКХ блоку «Туберкульоз» (рис. 5, б) виявив домінування 2-х нозологій: «А 15 - ТБ органів дихання, підтверджений бактеріологічно та гістологічно» $(37,08 \pm 30,24 \%)$ та «А19 - Міліарний ТБ» $(35,42 \pm 26,11 \%)$.

У літературних джерелах є дані [18], що випадки ТБ, чутливі до ПТП, переходять у випадки ТБ, резистентні до ПТП. Тому було здійснено порівняння діагнозів при госпіталізації та при виписуванні (смерті). Результат такого порівняння графічно представлений на рисунку 6.

Отже, перехід ТБ зі збереженою чутливістю мікобактерій до хіміотерапії до хіміорезистентного ТБ, у тому числі МРТБ, у даній вибірці становив 15,58 \%.

На рисунку 7 подано розподіл медичних карт хворих на ТБ / ВІЛ за причинами виписування пацієнтів із обласних ПтЗОЗ за аналізом пункту 12 Виписки 3 медичної картки стаціонарного хворого ТБ 09.

Отже, майже половина $(49,34 \pm 10,5$ \%) хворих на ко-інсекцію ТБ / ВІЛ закінчили етап лікування, який співпадав із припиненням бактеріовиділення, закінченням інтенсивної фрази хіміотерапії чи основного курсу антибіотикотерапії. Сумарно четвертина паці-

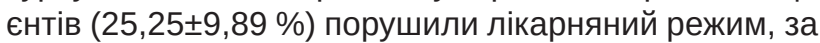

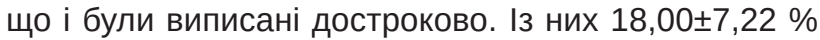
- самовільно покинули 303 і не повернулися на ви-

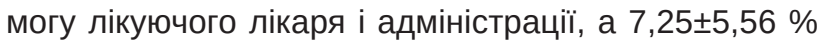
хворих виписали власне за порушення правил внутрішнього розпорядку: вживання алкогольних напоїв, неадекватне поводження із хворими у палаті чи медперсоналом, систематичне покидання 303 тощо. Ще одна чверть причин виписки хворих на ТБ / ВІЛ

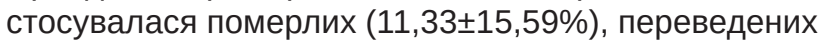
$(7,33 \pm 4,97 \%)$ чи виписаних за вимогою у вигляді письмової заяви $(6,75 \pm 3,51 \%)$. На рисунку 8 поданий ряд обласних ПТЗОЗ за причинами виписування хворих

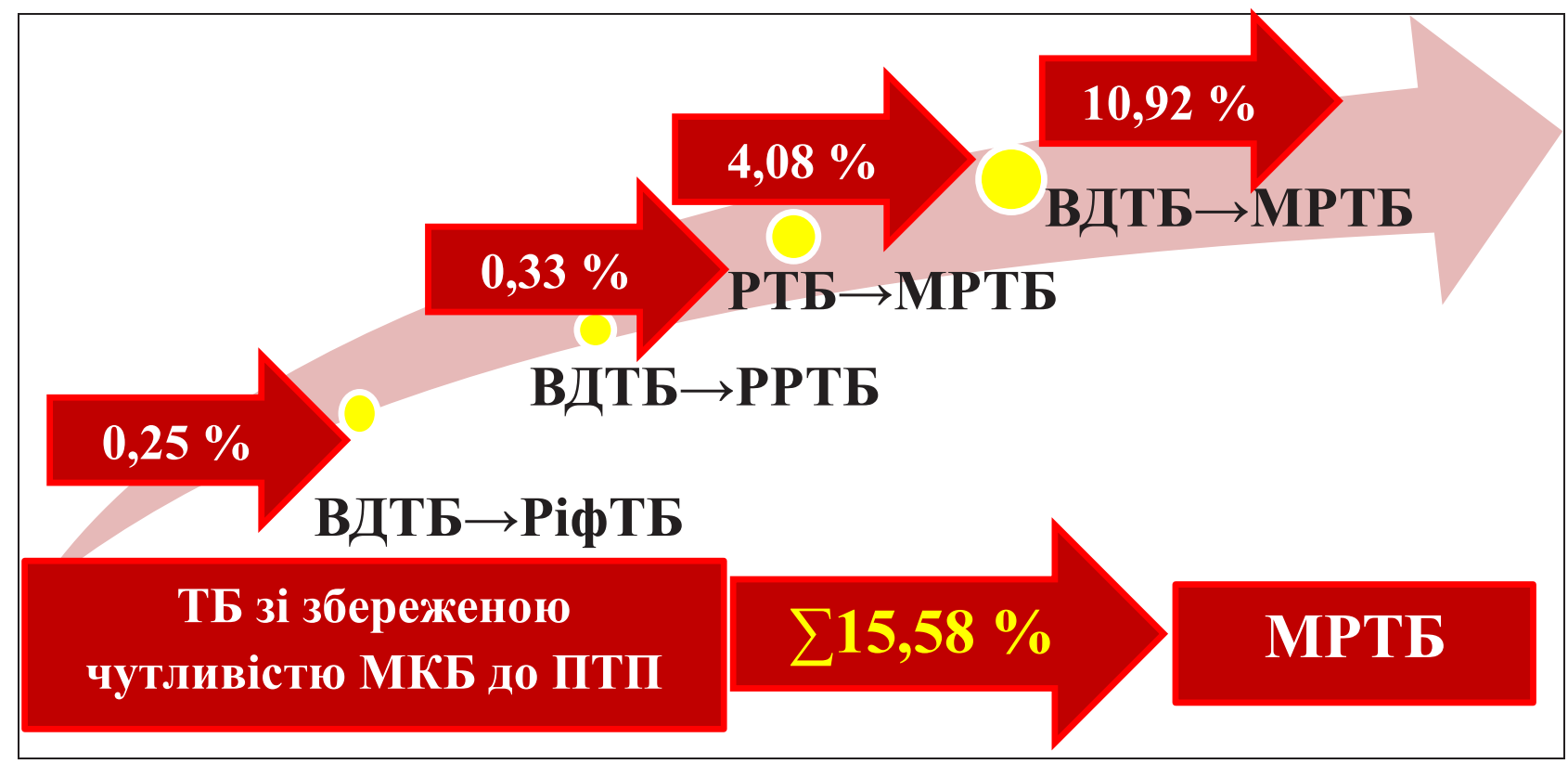

Рис. 6. Результат визначення частки переходу випадків ТБ, чутливих до ПТП, до стійких до ПТП у хворих на ТБ / ВІЛ.

ISSN 2312-0967. Pharmaceutical review. 2017. № 4 


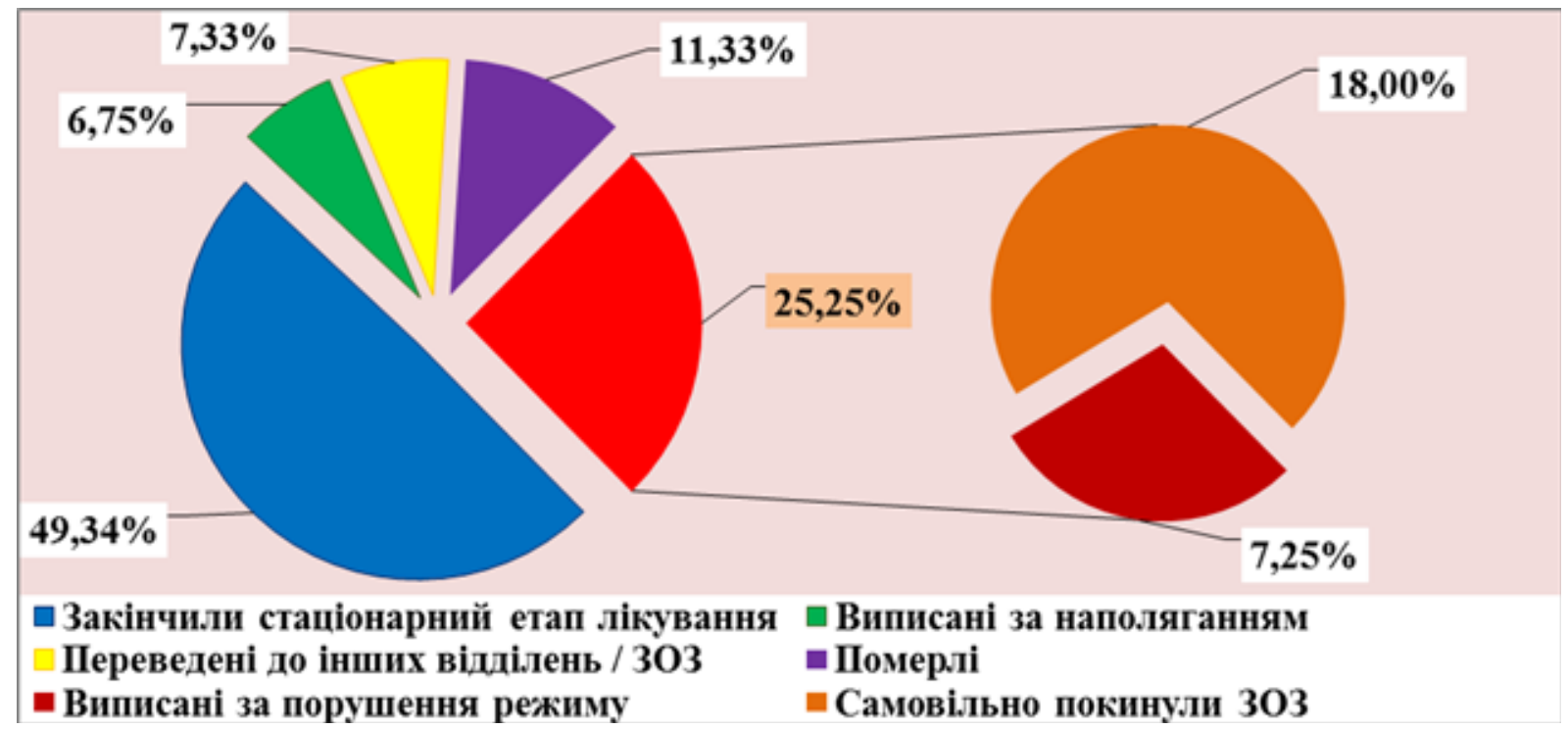

Рис. 7. Результати аналізу причин виписування хворих на ТБ / ВІЛ із ПТзОз.

Отже, результати аналізу цього соціо-індикатора, які подано на рисунку 8, свідчать, що найчастіше пацієнтів із ТБ / ВІЛ виписували через закінчення стаціонарного етапу лікування у м. Києві (67,59 \%), Одеській (64,76\%), Харківській (60 \%) областях, а найбільш недисципліновані пацієнти (за сумою причин «Самовільне залишення» і «Порушення режиму») були у Вінницькій (43,14\%), Запорізькій (41,91 \%), Львівській (36,00 \%) областях.

До соціо-індикаторів, інорормація про які доступна із Виписки із медичної картки амбулаторного (стаціонарного, санаторного) хворого ТБ 09, відноситься і кількість ліжко-днів, проведених пацієнтом у стаціонарі. Установлено, що в середньому 1200 хворих на ко-інфекцію ТБ / ВІЛ провели у стаціонарі $116 \pm 93$ ліжко-днів (рис. 9). Установлено, що найдовше пере-

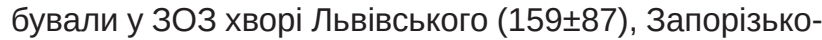

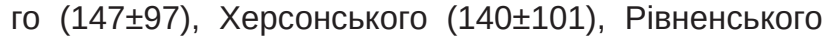
$(136 \pm 120)$, а найменше - Івано-Франківського

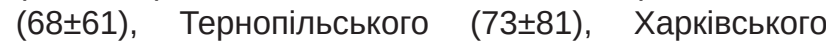

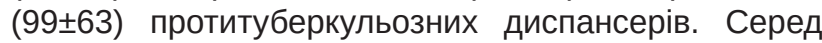
медичних карток хворих даної вибірки найдовша тривалість лікування була зафріксована у Дніпропетровській області: вона становила 910 ліжко-днів. Водночас були хворі, які перебували у 303 1-3 дні.

На основі вивчення тривалості перебування хворих первинної, випадково сорормованої, вибірки у стаціонарі були утворені групи медичних карток для фрармакоекономічного аналізу. Насамперед було відкинуто ті медичні картки, пацієнти яких за часом перебування у стаціонарі вийшли за рамки стандартних відхилень від середнього значення тривалості ліжко-днів.

Оскільки хворі на ТБ / ВІЛ у середньому перебува-

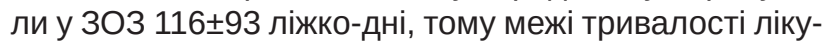
вання для цієї групи становили: 23 - 209 ліжко-днів. Тоді медичні карти, які задовольнили вказані межі, були піддані фрільтру заданих випадків ТБ на підставі попередньої історії лікування, а саме: МРТБ та ВДТБ. Таким чином були сорормовані вторинні вибірки медичних карток для проведення фрармакоекономічного аналізу спожитої хворими на ТБ / ВІЛ терапії за листками призначень лікарів для визначення ії̈ якісних та кількісних характеристик, що і окреслило перспективи подальших досліджень.

Висновки. У межах областей аналізу за соціально-демограсрічними характеристиками хворі на ТБ /

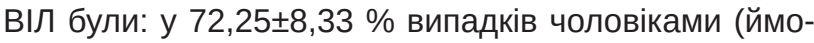
вірність належати до жіночої статі зростала в областях найвищої поширеності ВІЛ); у 94,41ะ2,32\% - віком 22-51 рр., в тому числі у 54,83 $\pm 8,1 \%-32-41$ рр.;

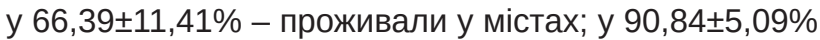
- відносились до соціально незахищених верст суспільства: були безробітними працездатного віку

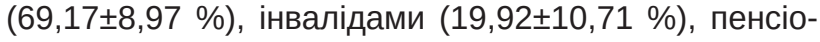
нерами $(0,83 \pm 1,31 \%)$, перебували у декретній відпустці $(0,67 \pm 0,99 \%)$, студентами $(0,25 \pm 0,56 \%)$, у тому числі належали до осіб без постійного місця проживання $(2,33 \pm 2,56 \%)$, були внутрішніми переселенцями $(0,92 \pm 1,7 \%)$, засудженими $(0,75 \pm 0,69 \%)$.

Виявлено, що в областях найбільшого розповсюдження ВІЛ виходить за межі «груп ризику», бо найвища частка працюючих (робітників, службовців, учасників АТО) була в Одеській $(17,14 \%)$, м. Києві (14,81 \%), Дніпропетровській (13,6 \%), Запорізькій (13,33 \%) областях. А загалом досліджувана вибірка пацієнтів на 91,0 \% була сорормована непрацюючими особами, які, окрім допомоги на Птп і антиретровірусну терапію, потребують фрінансування терапії ускладнень та супутніх хвороб. А ще для них вкрай доцільними є: постійний соціальний супровід для підвищення комплаєнсу, бесіди на теми необхідності закінчення розпочатого лікування, здорового та морального способу життя, жаги до життя і подолання

ISSN 2312-0967. Фармацевтичний часопис. 2017. № 4 
Фармакоекономіка

Pharmacoeconomics
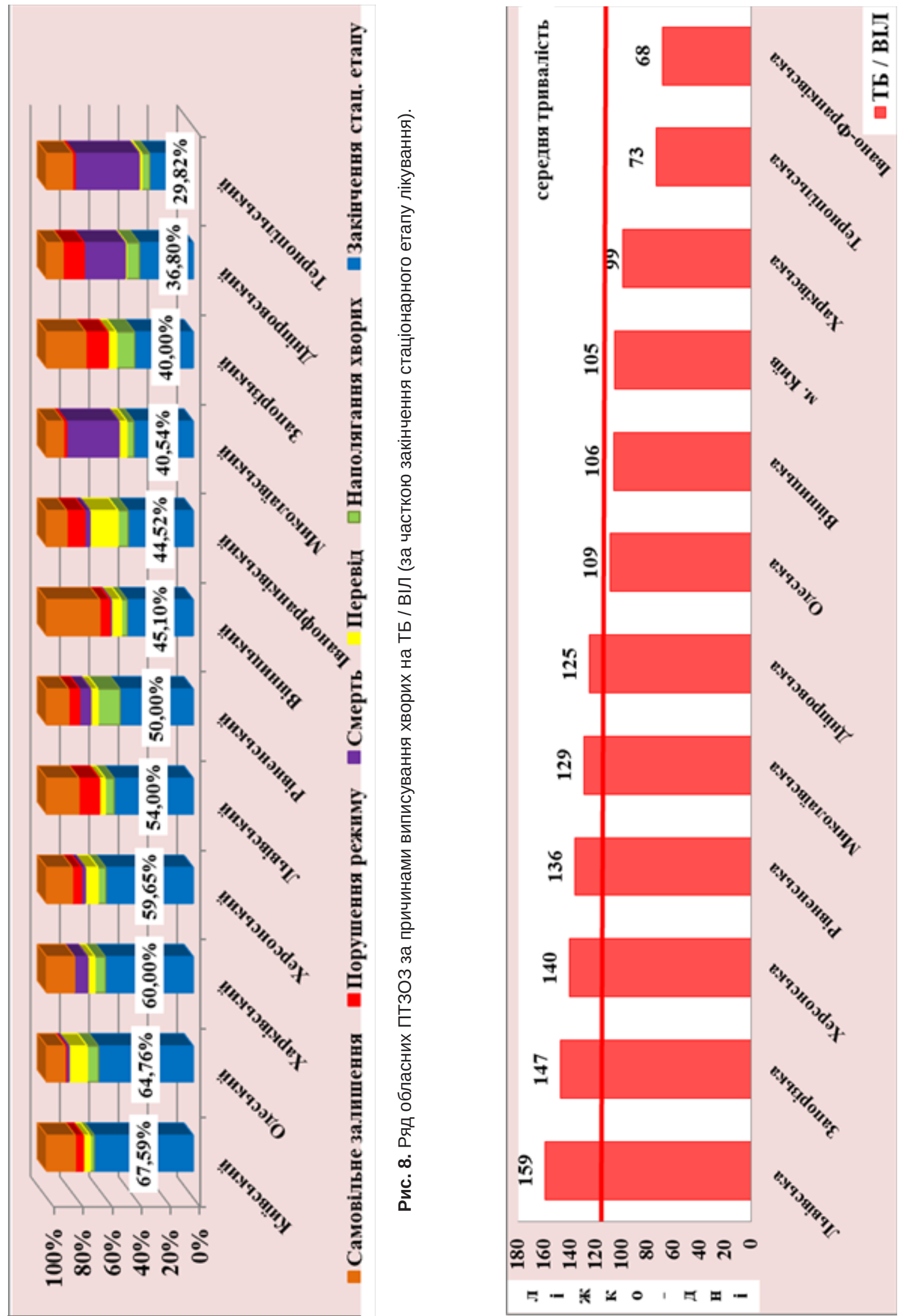

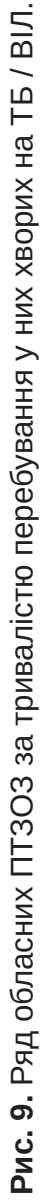


їх хвороб. Адже з усіх виписаних пацієнтів із ТБ / ВІЛ лише 49,34 \% осіб закінчили стаціонарний етап лікування, який у середньому тривав $116 \pm 93$ ліжко-дні, і аж 25,25 \% були виписані за порушення лікарняного режиму: самовільно залишили стаціонар 18,0 \% осіб, порушили правила перебування у 303, насамперед через пияцтво 7,25 \%. В основному через перерву у терапії ВДТБ у 16 \% осіб відбувся перехід ТБ зі збереженою чутливістю до ПТП 1 ряду у лікостійкий ТБ.

Водночас соціальні індикатори ТБ/ВІЛ, які стосувалися перебування хворих у протитуберкульозних закладах, найперше залежали від регіону проживання, на що вказали високі значення стандартних відхилень.

\title{
АНАЛИЗ СОЦИАЛЬНЫХ ИНДИКАТОРОВ ЭПИДЕМИИ ТБ / ВИЧ В УКРАИНЕ
}

\section{И. О. Федяк, П. И. Федяк}

ГвУз «Ивано-Франковский национальный медицинский университет»

Irynaf@tvnet.if.ua

Цель работы. Основываясь на анализе данных медицинской карты стационарного больного Ф003/о, определить и оценить социальные индикаторы ко-иноекции ТБ/ВИЧ в Украине.

Материалы и методы. 1200 медицинских карт стационарных больных ТБ / ВИЧ в диапазоне «А15-А19 Туберкулез» с ВИЧ-инфекцией случайно отобраны из архивов 12-ти областныхпротивотуберкулезных диспансеров (с сохранением тайны персональных данных больных); социологический метод анализа документов (формализованный, контентанализ).

Результаты и обсуждение. Исследуемую выборку пациентов с ТБ/ВИЧ на 91\% составили неработающие лица, нуждающиеся в постоянном социального сопровождения. Ибо из всех выписанных только 49,34\% больных

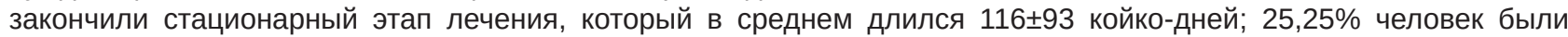
выписаны за нарушение больничного режима (18\% - самовольно оставили стационар, 7,25\% - нарушили другие правила пребывания). Поскольку самая высокая доля работающих лиц с ТБ/ВИЧ оказалась в областях высокой распространенности ВИЧ-инфекции: Одесской $(17,14 \%)$, г. Киеве $(14,81 \%)$, Днепропетровской (13,6\%), Запорожской (13,33\%), можно предположить, что ВИЧ-инфекция в Украине выходит за пределы «групп риска».

Выводы. В рамках областей анализа по социально-демографическим характеристикам больные ТБ/ВИч были в 72,25 $\pm 8,33 \%$ случаев мужчинами (вероятность принадлежать к женскому полу росла в областях высокой

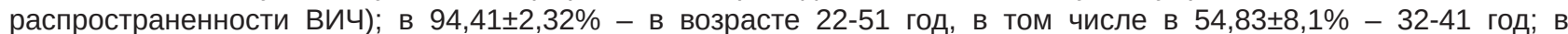

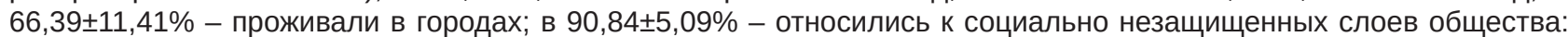
были безработными трудоспособного возраста $(69,17 \pm 8,97 \%)$, инвалидами $(19,92 \pm 10,71 \%)$, пенсионерами $(0,83 \pm 1,31 \%)$, находились в декретном отпуске $(0,67 \pm 0,99 \%)$, студентами $(0,25 \pm 0,56 \%)$, в том числе принадлежали к лицам без определенного места жительства $(2,33 \pm 2,56 \%)$, были внутренними переселенцами $(0,92 \pm 1,7 \%)$, осужденными $(0,75 \pm 0,69 \%)$. В то же время социальные индикаторы ТБ/ВИЧ, которые касаются пребывания больных в противотуберкулезных учреждениях, прежде всего зависели от региона.

Ключевые слова: ко-инфекция ТБ/ВИЧ; медицинская карта стационарного больного Ф003/о; социальныеиндикаторы; социально-демографрические характеристики индивида; причина выписки больного, койко-день.

\section{ANALYSIS OF SOCIAL INDICATORS OF TB I HIV EPIDEMY IN UKRAINE}

\author{
I. O. Fedyak, P. I. Fedyak \\ Ivano-Frankivsk National Medical University \\ Irynaf@tvnet.if.ua
}

The aim of the work. Based on the analysis of the data of the hospital patient's form No. 003/o, to determine and evaluate social indicators of co-infection TB / HIV in Ukraine.

Materials and Methods: 1.200 medical cards for inpatients with TB/HIV in the range of nosology "A15-A19 Tuberculosis" with HIV-infection, randomly selected from the archives of 12 regional anti-TB dispensaries (with the preservation of personal data of patients); sociological method of document analysis (formalized, content analysis).

Results and Discussion. The random of TB / HIV patients was $90.84 \%$ related to the unemployed population, which needs constant social support. Because among all patients, there were only $49.34 \%$ of the patients that completed the inpatient stage of treatment, which in average was $116 \pm 93$ bed days; $25.25 \%$ of patients were discharged for violation of the hospital regime (18\% - left the hospital by their own, $7.25 \%$ violated other rules of remaining). As the highest

ISSN 2312-0967. Фармацевтичний часопис. 2017. № 4 
proportion of working people with TB / HIV appeared in the areas of the highest HIV prevalence: Odesa region (17.14 \%), Kyiv (14.81 \%), Dnipropetrovsk region (13.6\%), Zaporizhzhia (13.33\%), we can assume that HIV infection goes beyond the «risk groups».

Conclusions. Within the areas of socio-demographic analysis, patients with TB / HIV were: in $72.25 \pm 8.33 \%$ male (the probability of being female was increasing in the areas of the highest HIV prevalence); in $94.41 \pm 2.32 \%-$ at the age of 22-51 (54.83 $\pm 8.1 \%$ - 32-41 years); $66.39 \pm 11.41 \%$ - lived in cities; $90.84 \pm 5.09 \%$ - belonged to socially unprotected people of the society: there were unemployed persons of working age $(69.17 \pm 8.97 \%)$, disabled persons $(19.92 \pm 10.71 \%)$, pensioners $(0.83 \pm 1.31 \%)$, persons on maternity leave $(0.67 \pm 0.99 \%)$, students $(0.25 \pm 0.56 \%)$, including those without permanent residence $(2.33 \pm 2.56 \%)$, internally displaced $(0.92 \pm 1.7 \%)$, convicted $(0.75 \pm 0.69 \%)$. At the same time, the social indicators of TB / HIV related to the remain patients in anti-TB dispensaries depended primarily on the region of residence.

Key words: co-infection with TB / HIV; medical card of a stationary patient form No. 003/o; social indicators; sociodemographic characteristics of the individual; the reason for the patient's discharge.

\section{Список літератури}

1. WHO. Global Tuberculosis Report 2016 [Electronic resource] // World Health Organization. - 2016. - Access mode: URL : http://apps.who.int/iris/bitstream/ 10665/250441/1/9789241565394-eng.pdf?ua=1.

2. WHO's Global TB database [Electronic resource]. - Access mode: URL : https://extranet.who.int/sree/Reports?op= Replet\&name=\%2FWHO_HQ_Reports\%2FG2\%2FPROD\%2 FEXT\%2FTBCountryProfile\&ISO2=UA\&LAN=RU\&outt.

3. Чинники ризику прогресування та критерії оцінки перебігу ВІЛ/СНІД-асоційованого туберкульозу легень [Текст] / О. С. Шальмін, Р. М. Ясінський, О. А. Растворов, Д. В. Мірошниченко // Туберкульоз, легеневі хвороби, ВІЛ-інфрекція. - 2014. - № 4. - С. 58-63.

4. Кірієнко І. А. ВІЛ-асоційований туберкульоз [Текст] / І. А. Кірієнко, В. П. Регнер // Ліки України. - 2013. - № 6. - C. 27-33.

5. Габорець Т. Л. Сучасний підхід до організації медичної допомоги хворим на ВІЛ-асоційований туберкульоз в Україні за принципом «дві хвороби - один пацієнт» [Текст] / Т. Л. Габорець // Туберкульоз, легеневі хвороби, ВІЛ-інсекцція. - 2014. - № 3. - С. 90- 96.

6. Нізова Н. М. Партнерство України з Глобальним фондом для боротьби зі СНІДом, туберкульозом та малярією як чинник зміцнення ролі держави у сорері протидії ВІЛ-інфекції/СНІДу в Україні [Текст] / Н. М. Нізова // Туберкульоз, легеневі хвороби, ВІЛ-інфрекція. 2012. - № 3. - С. 6-12.

7. Центр громадського здоров'я МО3 України Туберкульоз. Епіднагляд [Електронний ресурс]. - Режим доступу : URL : https://phc.org.ua/pages/diseases/tuberculosis/surveillance.

8. Туберкульоз в Україні: аналітично-статистичний довідник [Електронний ресурс] / MO3 України. ДУ «Український центр контролю за соціальнонебезпечними хворобами МОЗ України» / /Київ: БланкПрес, 2015. - Режим доступу: URL : http://www.slideshare.net/Ukraine CDC/2014-52881494.

9. Немченко А. С. Дослідження міжнародного досвіду впровадження оцінки технологій в охороні здоров'я [Текст] / А. С. Немченко, К. Л. Косяченко // Фармацевт. журнал. - 2011. - № 5. - С. 50-54.
10. Піняжко О. Б. Методичні підходи до проведення оцінки технологій охорони здоров'я в Україні на основі європейської моделі [Текст] / О. Б. Піняжко, О.М.Заліська // Соц. фрармація в охороні здоров. - 2015. - Т. 1, № 2. - C. 44-54.

11. Ясинов Д. А. Эфрфективность психологического сопровождения приверженности к лечению туберкулеза на стационарном этапе [Текст] / Д. А. Ясинов, И. А. Половинко, Л. Т. Смагина // Туберкульоз, легеневі хвороби, ВІЛ-інфекція. - 2014. - № 1 (16). - С. 55-59.

12. Федяк I. О. Аналіз статусу ВІЛ-інсрікованих пацієнтів В областях 3 найвищою поширеністю ВІЛ-інфрекції [Текст] / І. О. Федяк, Д. В. Семенів // Профр. медицина: епідем., мікробіоол., вірусом., паразитол., інфекц. хвор. - 2016. - № 3-4 (27). - С. 149-151.

13. Федяк І. О. Дослідження медико-соціального портрету пацієнта і пріоритетності серед схем антиретровірусної терапії у вітчизняних регіональних центрах СНІДУ [Текст] / І. О. Федяк // Фармацевт. журнал. - 2016. - № 6. - С. 40-49. 14. Дворецька Г. В. Соціологія: Навчальний посібник [Текст] / Г. В. Дворецька - вид. 3-тє, перероб. і доп. - К. : KHEУ, 2013. -428 с.

15. Інструкція щодо заповнення форми первинної облікової документації № 003/о «Медична карта стаціонарного хворого № __ [Текст]: наказ МОЗ України від 14.02.2012 р. № 110 «Про затвердження фрорм первинної облікової документації та Інструкцій щодо їх заповнення, що використовуються у 303 незалежно від фрорми власності та підпорядкування» - Офріційний вісник України. - 2012. - № 41. - 64 с.

16. Macionis J.J. Sociology [Text] / Macionis J.J. - Pearson, 2017. - 744 p.

17. Plummer Ken. Sociology: The Basics 2nd Edition [Text] I Ken. Plummer. - Routledge, 2016. - 302 p.

18. Уніфікований клінічний протокол первинної, вторинної (спеціалізованої) та третинної (високоспеціалізованої) медичної допомоги. Ко-інсрекція (Туберкульоз / ВІЛінфрекція/СНІД) [Текст]: наказМОЗУкраїни від 31.12.2014 p. № 1039 «Про затвердження та впровадження медикотехнологічних документів зі стандартизації медичної допомоги при туберкульозі» - Київ, 2014. - 211 с.

ISSN 2312-0967. Pharmaceutical review. 2017. № 4 


\section{References}

1. WHO. Global Tuberculosis Report 2016 [Electronic resource]. World Health Organization, 2016. Available from: http://apps.who.int/medicinedocs/documents/ s23098en/ s23098en.pdf. [Accessed November 2017].

2. WHO's Global TB database [Electronic resource]. World Health Organization, 2016. Available from: https://extranet. who.int/sree/Reports?op=Replet\& name=\%2FWHO_HQ Reports\%2FG2\%2FPROD\%2FEXT\%2FTBCountryProfil e\&ISO2=UA\&LAN=RU\&outt. [Accessed November 2017].

3. Shalmin OS, Yasinskyi RM, Rastvorov OA, Miroshnychenko DV. [Factors of progression risk and criteria for assessing the course of HIVIAIDS-associated pulmonary tuberculosis]. Tuberkuloz, lehenevi khvoroby, VIL-infektsiia. 2014;4: 58-63. Ukrainian.

4. Kiriienko IA, Rehner VP. [HIV-associated tuberculosis]. Liky Ukrainy. 2013;6: 27-33. Ukrainian.

5. Haborets TL. [A modern approach to the organization of medical care for patients with HIV-associated tuberculosis in Ukraine on the basis of the principle of «two illnesses one patient»]. Tuberkuloz, lehenevi khvoroby, VIL-infektsiia. 2014;3: 90-6. Ukrainian.

6. Nizova NM. [Ukraine's partnership with the Global Fund to fight AIDS, tuberculosis and malaria as a factor for strengthening the state's role in the area of HIVIAIDS response in Ukraine]. Tuberkuloz, lehenevi khvoroby, VILinfektsiia. - 2012;3: 6-12. Ukrainian.

19. Center for Public Health Ministry of Health of Ukraine. Tuberculosis. Epidemiology Base [Electronic resource] Ukrainian. Available from: https://phc.org.ua/pages/diseases/tuberculosis/surveillance. [Accessed November 2017].

7. Tuberculosis in Ukraine: analytical and statistical guide. Ukrainian Center for the Control of Socially Dangerous Diseases Ministry of Health of Ukraine, 2015 [Electronic resource, Ukrainian]. Available from: http://www.slideshare. net/ Ukraine_CDC/2014-52881494. [Accessed November 2017].

8. Nemchenko AS, Kosiachenko KL. [Investigation of international experience in technology assessment in health care]. Farmatsevt zhurn. 2011;5: 50-4. Ukrainian.

9. Piniazhko OB, Zaliska OM. [Methodological approaches to the evaluation of health technologies in Ukraine on the basis of the European model]. Sotsialna farmatsiia v okhoroni zdorovia. 2015;2: 44-54. Ukrainian.

10. Iasynov DA, Polovynko YA, Smahyna LT. [Efficiency of psychological support of adherence to treatment of tuberculosis at the stationary stage]. Tuberkuloz, lehenevi khvoroby, VIL-infektsiia. 2014;1: 55-9. Russian.

11. Fediak IO, Semeniv DV. [Analysis of the status of HIVinfected patients in the areas with the highest prevalence of HIV infection]. Profilaktychna medytsyna: epidemiolohiia, mikrobiolohiia, virusolohiia, parazytolohiia, infektsiini khvoroby. 2016;3-4: 149-151. Ukrainian.

12. Fediak IO. [Research of medical and social portrait of the patient and priority among schemes of the antiretroviral therapy in the national regional AIDS centers]. Farmatsevt zhurn. 2016;6: 40-9. Ukrainian.

13. Dvoretska HV. Sociology: A manual. [Соціологія: Навчальний посібник] Kyiv: Kyiv National Economic University named after Vadym Hetman; 2013. Ukrainian.

14. Nakaz Ministerstva okhorony zdorovia Ukrainy vid 14.02.2012 № 110 «Pro zatverdzhennia form pervynnoi oblikovoi dokumentatsii ta Instruktsii shchodo yikh zapovnennia, shcho vykorystovuiutsia u zakladakh okhorony zdorovia nezalezhno vid formy vlasnosti ta pidporiadkuvannia» Available from: http://zakon3.rada.gov.ua/laws/show/ z0661-12.

15. Macionis JJ. Sociology. Pearson; 2017.

16. Plummer Ken. Sociology: The Basics 2nd Edition. Routledge; 2016.

17. Nakaz Ministerstva okhorony zdorovia Ukrainy vid 31.12.2014 № 1039 «Unifikovanyi klinichnyi protokol pervynnoi, vtorynnoi (spetsializovanoi) ta tretynnoi (vysokospetsializovanoi) medychnoi dopomohy. Ko-infektsiia (Tuberkuloz / VIL-infektsiia/SNID)» Available from: http:// mtd.dec.gov.ua/ images/dodatki/2014_1039_Ko_VIL_ SNID/2014_1039_nakaz.pdf. 